DOI https://doi.org/10.30525/978-9934-26-046-9-8

\title{
ДО ПИТАННЯ РОЗВИТКУ СИСТЕМ ПІДТРИМКИ ПРИЙНЯТТЯ РІШЕННЯ НА ОСНОВІ ІНФОРМАЦЙНИХ ТЕХНОЛОГІЙ ВІЙСЬКОВОГО ПРОГНОЗУВАННЯ
}

\author{
Кубявка М. Б. \\ кандидат технічних наук, старший науковий співробітник \\ Військовий інститут \\ Київського наџіонального університету імені Тараса Шевченка
}

Охрамович М. М.

кандидат технічних наук, старший науковий співробітник

Військовий інститут

Київського начіонального університету імені Тараса Шевченка

\author{
Коваль М. О. \\ молодиий науковий співробітник \\ Військовий інститут \\ Київського національного університету імені Тараса Шевченка \\ м. Київ, Украӥна
}

Ефективність дій військ у бою буде високою лише за умови чіткого визначення мети і завдань, які $\epsilon$ наслідком аналізу реальних умов ведення бою, чіткому визначенні сил, засобів і способів дій військ (сил) щодо досягнення цієї мети, матеріально-технічним забезпеченням.

Відповідно прийняття командирами ефективних і своєчасних рішень під час підготовки та ведення бойових дій в умовах невизначених і постійно змінних способів ведення війни на фоні основного удару інформаційної політики країни-агресора, який спрямований на маніпуляцію свідомістю та дестабілізацію країни зсередини [1], стає актуальною задачею, яку найскоріше потрібно вирішувати.

Саме системи підтримки прийняття рішень (СППР) і $є$ тими інформаційними технологіями, які, на сьогоднішній день, забезпечують прийняття раціональних рішень командирами в умовах жорсткого дефіциту часу та високого рівня відповідальності за можливі помилки.

А як оцінити той вплив, який несуть системи підтримки прийняття рішення на раціональну реакцію командира щодо ситуації, яка скла- 
дається? Як спрогнозувати найбільш можливу реакцію щодо прийняття рішення командиром після отримання ним інформації від системи підтримки прийняття рішення?

У результаті аналізу джерел [2-8], та враховуючи специфіки ведення війни в Україні виділяється раніше невирішена частина загальної проблеми, яка полягає в прогнозуванні розвитку подій після впливу системи підтримки прийняття рішення на командира щодо прийняття ним раціональних рішень. На думку авторів, використання нижче запропонованого способу дасть можливість більш досконало передбачати ймовірні прийняття рішень.

Будь-який інформаційний вплив на отримувача інформації призводить до змін ймовірностей його реакцій [9]. Система підтримки прийняття рішень надає командиру (начальнику) відповідну «підказку» в результаті якої формується саме те, найбільш оптимальне, його рішення. Відповідно оцінку впливу результату такого повідомлення можна представити як різницю між початковими (до впливу на командира) та кінцевими (після впливу) ймовірностями. Виходячи 3 цього запропоновано оцінити вплив на командира (начальника), через різницю в умовних та безумовних ймовірностях його реакцій на ці впливи.

Для вирішення поставленого завдання застосуємо результати отримані в попередніх роботах авторів щодо оцінки впливу на контрагентів взаємодії та автоматичному адресуванні повідомлень з урахуванням їх інформаційного впливу на адресатів, але з урахуванням специфіки задачі [10].

Так, рішення будь якого командира (начальника) можна, з певною ймовірністю, передбачити за рахунок тих впливів, які на нього здійснюються.

Тобто, вироблення раціонального чи оптимального рішення командиром буде напряму залежати від тієї інформації яка надходитиме йому від СППР.

Виходячи 3 позиції, що будь який інформаційний вплив призводить до збільшення чи зменшення ймовірності прийняття людиною якогось рішення

$$
p\left(R_{i}\right) \neq p\left(R_{i} / A_{j}\right),
$$

де $p\left(R_{i}\right)$ - безумовна ймовірність прийняття рішення $R i$ командира (визначена його початковою інформованістю); 
Тоді, якщо після такого інформаційного наповнення командир приймає раціональні чи оптимальні рішення, то, відповідно, чим більш релевантна інформація надається йому, тоді і ймовірність прийняття ним необхідних рішень збільшується. Зрозуміло що існують підмножини впливу

$$
\begin{aligned}
& A^{+}=\left\{A_{j_{k}}\right\}, k=\overline{1, n^{+}} ; \\
& A^{-}=\left\{A_{j_{l}}\right\}, l=\overline{1, n^{-}},
\end{aligned}
$$

де $p\left(R_{i} / A_{j_{k}}\right)>p\left(R_{i}\right) ; p\left(R_{i} / A_{j_{l}}\right) \leq p\left(R_{i}\right)$;

$n^{+}-$кількість «позитивних» впливів;

$n-$ кількість «негативних» впливів,

i, незважаючи на те, що інформація що надходить від СППР має вектор лише «позитивного» впливу, а нерелавантне уже відкинуте, залишається певна вірогідність, що надана «допомога» в прийнятті рішення буде розцінена командиром в супереч нашим сподіванням.

Вплив на командира запропоновано вимірювати величиною (зростання) ймовірності безумовної події прийняття ним відповідного рішення та визначати через відхилення умовної ймовірності, від безумовної. Представимо таку оцінку формулою

$$
w\left(R_{i} / A_{j_{k}}\right)=\frac{p\left(R_{i} / A_{j_{k}}\right) \cdot\left(1-p\left(R_{i}\right)\right)}{\left(1-p\left(R_{i} / A_{j_{k}}\right)\right) \cdot p\left(R_{i}\right)},
$$

де $w\left(R_{i} / A_{j_{k}}\right)$ - оцінка величини впливу $A_{j_{k}}$ на прийняття рішення $R_{i}$.

Перейдемо від величини впливу до ймовірності прийняття рішення $R_{i}$ при багатогранності «підказки» СППР. Для цього пропонується застосувати наступну формулу

$$
w\left(R_{i} / A^{+}\right)=\sum_{k=1}^{n^{+}}\left[w\left(R_{i} / A_{j_{k}}\right)-1\right]+1
$$

де $w\left(R_{i} / A^{+}\right)$- оцінка величини всіх позитивних впливів на прийняте рішення $R_{i}$.

Тепер використовуючи формули (2) і (3) можна перейти до нової ймовірності прийняття командиром відповідного рішення: 


$$
p\left(R_{i} / A^{+}\right)=\frac{w\left(R_{i} / A^{+}\right) \cdot p\left(R_{i}\right)}{1+p\left(R_{i}\right) \cdot\left(w\left(R_{i} / A^{+}\right)-1\right)},
$$

де $p\left(R_{i} / A^{+}\right)$- ймовірності прийняття відповідного рішення $R_{i}$ після всіх позитивних впливів $A^{+}$на командира (начальника).

Висновки. У роботі авторами висвітлено один із варіантів застосування теорії несилової взаємодії, а саме в цілях військового прогнозування, як засобу оцінки прийняття ефективних командирських рішень. Базуючись на проведених попередніх дослідженнях, авторами вирішено задачу оцінки впливу системи на прийняття рішення командира (начальника) на основі представлення такої оцінки як різниці між початковими (до впливу на командира) та кінцевими (після впливу) ймовірностями.

Використання запропонованої моделі, на думку авторів, наближає нашу країну до створення ефективних інформаційних технологій підтримки прийняття рішень та військового прогнозування, що стане одним із вирішальних важелів щодо отримання інформаційної військової переваги над ворогами нашої Батьківщини.

\section{Література:}

1. Реалії інформаційної війни в Україні. URL: http:// www.milnavigator.com/uk/realiï-informacijnoï-vijni-v-ukraïni. (дата звернення: 09.01.2021).

2. Антонов В.М., Пермяков О.Ю. Комп’ютерні мережі військового призначення. К: «MК-Прес», 2005. - 320 с.

3. Черноруцкий И.Г. Методы принятия решений. - СПб.: БХВ-Петербург, 2005. - 416с.

4. Братушка С.М., Новак С.М., Хайлук С.О. Системи підтримки прийняття рішень: навч. посібник. Суми: ДВНЗ «УАБС НБУ», 2010. -265 c.

5. Колмогоров А.Н. Проблемы теории вероятностей и математической статистики// Вестник АН СССР. 1965. Вип. 5. С. 95

6. Ларичев О.И. Теория и методы принятия решений. - 2-е изд., перераб. и доп. - М.: Логос, 2002. - 392 с.

7. Демиденко М.А. Системи підтримки прийняття рішень: навч. посіб. Нац. гірн. ун-т. Д.: 2016. 104 с. - URL: http://nmu.org.ua (дата звернення: 09.01.2021).

8. Тесля Ю.М., Кубявка Л.Б., Миколенко А.О., Кубявка М.Б. Використання технологій інформаційного впливу під час підготовки та ведення бойових дій. СІТСБО. К: 2014. Вип. 2 (20)/2014. С.147-152. 
9. Тесля Ю.Н. Несиловое взаимодействие. - К: Кондор, 2005. - $196 \mathrm{c}$.

10. Кубявка М.Б. Моделі та методи управління інформаційним супроводженням в умовах гібридної війни: автореф. дис... канд. техн. наук: 05.13.06, Київ. нац. ун-т ім. Т.Шевченка. Київ, 2017. - 24 с.

DOI https://doi.org/10.30525/978-9934-26-046-9-9

\title{
ПЕРСПЕКТИВИ ВИКОРИСТАННЯ БПЛА В ІНФОРМАЦИЙНО- ТЕЛЕКОМУНІКАЦІЙНИХ МЕРЕЖАХ КРИТИЧНОГО ПРИЗНАЧЕННЯ
}

\author{
Лаврут О. О. \\ доктор технічних наук, доцент, \\ професор кафедри тактики \\ Національна академія сухопутних військ \\ імені гетьмана Петра Сагайдачного
}

Лаврут Т. В.

кандидат географічних наук, дочент,

старший науковий співробітник науково-дослідного відділу (систем управління військами) Наукового иентру Сухопутних військ

Національна академія сухопутних військ

імені гетьмана Петра Сагайдачного

\author{
Опалинський В. Б. \\ викладач кафедри тактики \\ Національна академія сухопутних військ \\ імені гетьмана Петра Сагайдачного \\ м. Львів, Украӥна
}

Сьогодні у світовій науці активно розвивається напрям досліджень, пов'язаний 3 використанням безпілотних літальних апаратів (БПЛА). Використання БПЛА забезпечує вирішення різноманітних задач, наприклад, при картографуванні підстилаючої поверхні землі, забезпеченні повітряного моніторингу наземної території під час розвідувальних та пошуково-дослідних робіт, під час ліквідації наслідків надзвичайних ситуацій (НС) техногенного або природного походження, вимірювання та передачі в реальному режимі часу різноманітних 40 